\author{
Ivan Kostashchuk \\ DSc (Geography), Associate Professor of the Department of Geography of Ukraine and Regional Studies \\ e-mail: ivan_kostaschuk@ukr.net, ORCID ID: https://orcid.org/0000-0002-9338-4538 \\ Yuriy Fedkovych Chernivtsi National University, \\ Mykhailo Kotsyubynsky street, 2, building 4, Chernivtsi, 58012, Ukraine
}

\title{
TERRITORIAL ORGANIZATION OF CONFESSIONAL SPACE OF THE WESTERN REGIONS OF UKRAINE
}

The study is devoted to the coverage of the territorial organization of the modern confessional space of the regions of Western Ukraine, which was formed under the influence of complex historical and geographical factors, namely the formation of Ukraine, socio-political life of individual regions, the influence of Western civilization, national liberation movements, ethnic composition and more.

The Western Ukrainian region, to which we include 8 oblasts, namely: Zakarpattia, Lviv, Volyn, Rivne, Ternopil, IvanoFrankivsk, Chernivtsi and Khmelnytskyi, is distinguished by a high level of religious mosaic and activity of the population, which is manifested in high rates of provision with religious communities and organizations, a high proportion of those who consider themselves believers and attend worship services weekly or at least once a month, and other indicators. It is interesting that in the territory of Western Ukraine such historical and geographical lands are separated as Volyn, Zakarpattia, Halychyna, Northern Bukovina, Southern Bukovina, part of Dorohoishchyna and Podillya, which certainly emphasizes this region as special for studying the geographical features of the formation of confessional space. Orthodoxy in the study region predominates in Chernivtsi, Khmelnytskyi, Volyn, Rivne, and Zakarpattia oblasts, and Greek Catholicism predominates in Halychyna (Ivano-Frankivsk, Lviv, and Ternopil oblasts). It is interesting that Roman Catholics are quite prominent in the confessional structure in the Khmelnytskyi oblast, where Poles occupy a significant share in the ethnic structure. Protestantism is present in all regions, but it is most concentrated in Volyn and Northern Bessarabia. In Zakarpattia oblast there is a separate denomination - the Transcarpathian Reformed Church, which is mainly professed by Hungarians.

It is established that the confessional space differs not so much by administrative-territorial boundaries as by historicalgeographical regions, which confirms the idea of the main influence on the process of its formation of historical-geographical features of territory formation, ethnic composition, demographic processes and other socio-political factors. .

Key words: confessional space, Western Ukraine, religious activity of the population, Orthodoxy, Catholicism, Protestantism. УКРАЇНИ

Іван Костащук. ТЕРИТОРІАЬНА ОРГАНІЗАЦІЯ КОНФЕСІЙНОГО ПРОСТОРУ ЗАХДНИХ ОБЛАСТЕЙ

Дослідження присвячено висвітленню територіальної організації сучасного конфесійного простору регіонів Західної України, який сформувався під дією складних історико-географічних чинників, а саме формування території України, суспільно-політичного життя окремих регіонів, впливу західноєвропейської цивілізації, національно-визвольних рухів, етнічного складу населення тощо.

Західноукраїнський регіон, до якого ми відносимо 8 областей, а саме: Закарпатську, Львівську, Волинську, Рівненську, Тернопільську, Івано-Франківську, Чернівецьку та Хмельницьку, виділяється високим рівнем релігійної мозаїчності та активності населення, що проявляється у високих показниках забезпеченості населення і населених пунктів релігійними громадами та організаціями, високою часткою тих, хто вважає себе віруючими і відвідує щотижня або принаймні раз у місяць богослужіння, та іншими показниками. Цікавим є те, що на території Західної України виділяються такі історикогеографічні землі як Волинь, Закарпаття, Галичина, Північна Буковина, Південна Буковина, частково Дорогойщина та Поділля, що безумовно підкреслює цей регіон як особливий для дослідження географічних особливостей формування конфесійного простору. Православ'я в досліджуваному регіоні переважає у Чернівецькій, Хмельницькій, Волинській, Рівненській та Закарпатській областях, а на Галичині (Івано-Франківська, Львівська та Тернопільська області) переважає грекокатолицизм. Цікавим $є$ те, що римо-католики у конфесійній структурі досить помітними є у Хмельницькій області, де в етнічній структурі помітну частку займають поляки. Протестантизм представлений в усіх регіонах, проте найбільше він зосереджений на Волині та Північній Бессарабії. У Закарпатській області представлена окрема конфесія - Закарпатська реформаторська церква, яку в основному сповідують угорці.

Встановлено, що конфесійний простір вирізняється не так за адміністративно-територіальними межами, як за історико-географічними краями, що підтверджує думку про основний вплив на процес його формування історико-географічних особливостей формування території, етнічного складу населення, демографічних процесів та інших суспільно-політичних чинників.

Ключові слова: конфесійний простір, Західна Україна, релігійна активність населення, православ'я, католицизм, протестантизм.

\section{Иван Костащук. ТЕРРИТОРИАЛЬНАЯ ОРГАНИЗАЦИЯ КОНФЕССИОНАЛЬНОГО ПРОСТРАНСТВА}

\section{ЗАПАДНЫХ ОБЛАСТЕЙ УКРАИНЫ}

Исследование посвящено освещению территориальной организации современного конфессионального пространства регионов Западной Украины, которое сложилось под действием сложных историко-географических факторов, а именно формирования территории Украины, общественно-политической жизни отдельных регионов, влияния западноевропейской цивилизации, национально-освободительных движений, этнического состава населения и тому подобное.

(C) Kostashchuk I., 2020 
Западно-украинский регион, к которому мы относим 8 областей, а именно: Закарпатскую, Львовскую, Волынскую, Ровенскую, Тернопольскую, Ивано-Франковскую, Черновицкую и Хмельницкую, выделяется высоким уровнем религиозной мозаичности и активности населения, проявляется в высоких показателях обеспеченности населения и населенных пунктов религиозными общинами и организациями; высока доля тех, кто считает себя верующими и посещает еженедельно или по крайней мере раз в месяц богослужения, и другими показателями. Интересно, что на территории Западной Украины выделяются такие историко-географические земли: Волынь, Закарпатье, Галичина, Северная Буковина, Южная Буковина, частично Дорогойщина и Подолье, что безусловно подчеркивает этот регион как особый для исследования географических особенностей формирования конфессионального пространства. Православие в исследуемом регионе преобладает в Черновицкой, Хмельницкой, Волынской, Ровенской и Закарпатской областях, а в Галиции (Ивано-Франковская, Львовская и Тернопольская области) преобладает греко-католицизм. Интересно, что католики в конфессиональной структуре достаточно заметны в Хмельницкой области, где в этнической структуре заметную долю занимают поляки. Протестантизм представлен во всех регионах, однако больше всего он сосредоточен на Волыни и Северной Бессарабии. В Закарпатской области представлена отдельная конфессия - Закарпатская реформаторская церковь, которую в основном исповедуют венгры.

Установлено, что конфессиональное пространство отличается не столько по административно-территориальным границам, как по историко-географическим краям, и это подтверждает мнение о том, что основное влияние на процесс его формирования имеют историко-географические особенности формирования территории, этнического состава населения, демографических процессов и других общественно-политических факторов.

Ключевые слова: конфессиональное пространство, Западная Украина, религиозная активность населения, православие, католицизм, протестантизм.

Formulation of the research problem. The end of the twentieth century was marked by complex transformations in the social life of Ukrainian society. This affected almost all sectors of the economic complex, infrastructure, socio-cultural, religious and domestic life of the population, due to the collapse of the Soviet Union and the socialist system of government. Permission of free religion in 1988 led to drastic changes in the confessional space of the regions of Ukraine. Such changes were especially noticeable in Western Ukraine, where the Ukrainian Greek Catholic Church, banned for almost half a century, began to revive, and communities of the Ukrainian Autocephalous Orthodox Church and various Protestant groups began to resume work. Within a few years, Greek Catholicism had become the dominant trend in Halychyna, virtually displacing Orthodoxy. Such tendencies affected the socio-political and ethnocultural life of the population, as well as determined the geopolitical vector of the region's development. The confessional space played and continues to play an important role in shaping the worldview of society, as some denominations supported the pro-European vector of state development, while others leaned towards the Russian (at that time still Soviet) vector of geopolitical interaction. All this has led to certain territorial definitions in the confessional space of eight regions of western Ukraine, which can be traced quite clearly today, playing an important role in shaping the geopolitical, political, electoral, cultural and other spheres of public life in the region. Therefore, the topic of this study is quite relevant, has practical significance and reveals the features of the territorial organization of the confessional space of the western oblasts of Ukraine.

Analysis of recent research and publications. The study of the geography of religion in Ukraine is devoted to the works of such scientists of Ukraine as: L.V. Ataman, T.I. Bozhuk, Yu.Ya. Horodyskyi, F.D. Zastavnyi, L.V. Kliuchko, A.S. Kovalchuk, Yu.L. Kogatko, I.I. Kostaschuk, O.H. Kuchabskyi, O.O. Liubitseva, K.V. Mezentsev, K.A. Nemets, L.M. Nemets, S.V. Pavlov, B.O. Patiychuk, I.I. Rovenchak, L.I. Shevchuk, P.A. Shukanov and many others. It should be noted that the scientific works of L.V. Ataman are devoted to the study of the confessional space of the western regions of Ukraine (sacred spaces of Podillya), T.I. Bozhuk (confessional space is considered as the basis for the development of religious tourism), Yu.Ya. Gorodyskyi (pilgrimage of Lviv oblast), F.D. Zastavnyi, S.V. Pavlova, K.V. Mezentseva, O.O. Lyubitseva (confessional space of the regions of Ukraine), A.S. Kovalchuk (confessional space of the regions of Ukraine and Lviv oblast in particular), I.I. Kostashchuk (confessional space of separate regions of Western Ukraine), O.G. Kuchabsky, I.I. Rovenchak and L.I. Shevchuk (Lviv oblast), V.O. Patiychuk (Volyn oblast) and others. However, their study is mainly chronological data of the late twentieth century, which do not take into account current trends in the confessional space, which are not sufficiently studied.

Identification previously unsolved parts of the scientific problem. Despite the high scientific and practical relevance of this study, today there is almost no scientific work that would reveal the confessional space of certain administrative-territorial or historicalgeographical units of Western Ukraine in order to further use it in shaping the strategy of state-confessional relations, including tourism activities, material and spiritual culture, social and humanitarian spheres, etc. Also an important aspect of research on religious development is the analysis of the impact of its territorial differences, which have developed in different historical and geographical areas of the studied region, on the geopolitical, cultural, mental, social development of the region.

Setting objections of the article. The main objectives set by the author during the research were to substantiate the place of the western regions of Ukraine among others, in terms of religious activity of the population; coverage of the modern territorial organization of the confessional space of the studied region, as well as the identification of factors that determine its formation in the region.

Presentation of the main research material. Western Ukraine is a region of Ukraine that covers the oblasts lying in its western part. There are different scientific approaches and views for defining the concept of "Western Ukraine" and establishing its borders, which are analyzed in the works of such scientists: M. Biletsky and A. Tolpigo, V. Popovkin, V. Bashtannyk, I. Belebykh, V. Bakum, V. Tikhonov, O. Shabliy, 
M. Dolishny, M. Palamarchuk, O. Palamarchuk, S. Teleshun, V. Gureyev, B. Danylyshyn, O. Marynych, F. Zastavny, M. Palamarchuk, M. Pistun, S. Doroguntsov, A. Fedoryshchev, P. Maslyak, P. Shishchenko, V. Krul and others, as well as the Institute of Geography of the NAS of Ukraine, the Institute of Regional Studies of the NAS of Ukraine and the Council for the Study of Productive Forces of Ukraine of the NAS of Ukraine. All offer somewhat different schemes of socio-geographical and historicalgeographical zoning of the territory of Ukraine. Therefore, based on the specifics of the formation of religious space in the western regions of Ukraine, we chose to study the region of Western Ukraine within the limits outlined by O.I. Shabliy. These borders also coincide with the borders of Western Ukraine in the zoning of V. Bashtannyk and the borders of Halychyna in the works of $\mathrm{V}$. Tikhonov. Thus, in the region of Western Ukraine in our research we include 8 regions: Zakarpattia, Lviv, Ivano-Frankivsk, Chernivtsi, Ternopil, Khmelnytskyi, Volyn and Rivne.

In historical and geographical terms, these oblasts are joined by the following historical and geographical regions (according to V.P. Krul): Zakarpattia (Zakarpattia oblast), Halychyna (Ivano-Frankivsk, Lviv and most of Ternopil oblast), Northern Bukovina, Northern Bessarabia, part of Dorohoishchyna (Chernivtsi oblast), part of Podillya (Khmelnytskyi oblast) and part of Volyn (Volyn, Rivne, northern Ternopil and part of Khmelnytskyi oblast), which certainly allows us to better trace the influence of historical, geographical, ethnic and other factors on the formation of religious space (Fig. 1) [1].

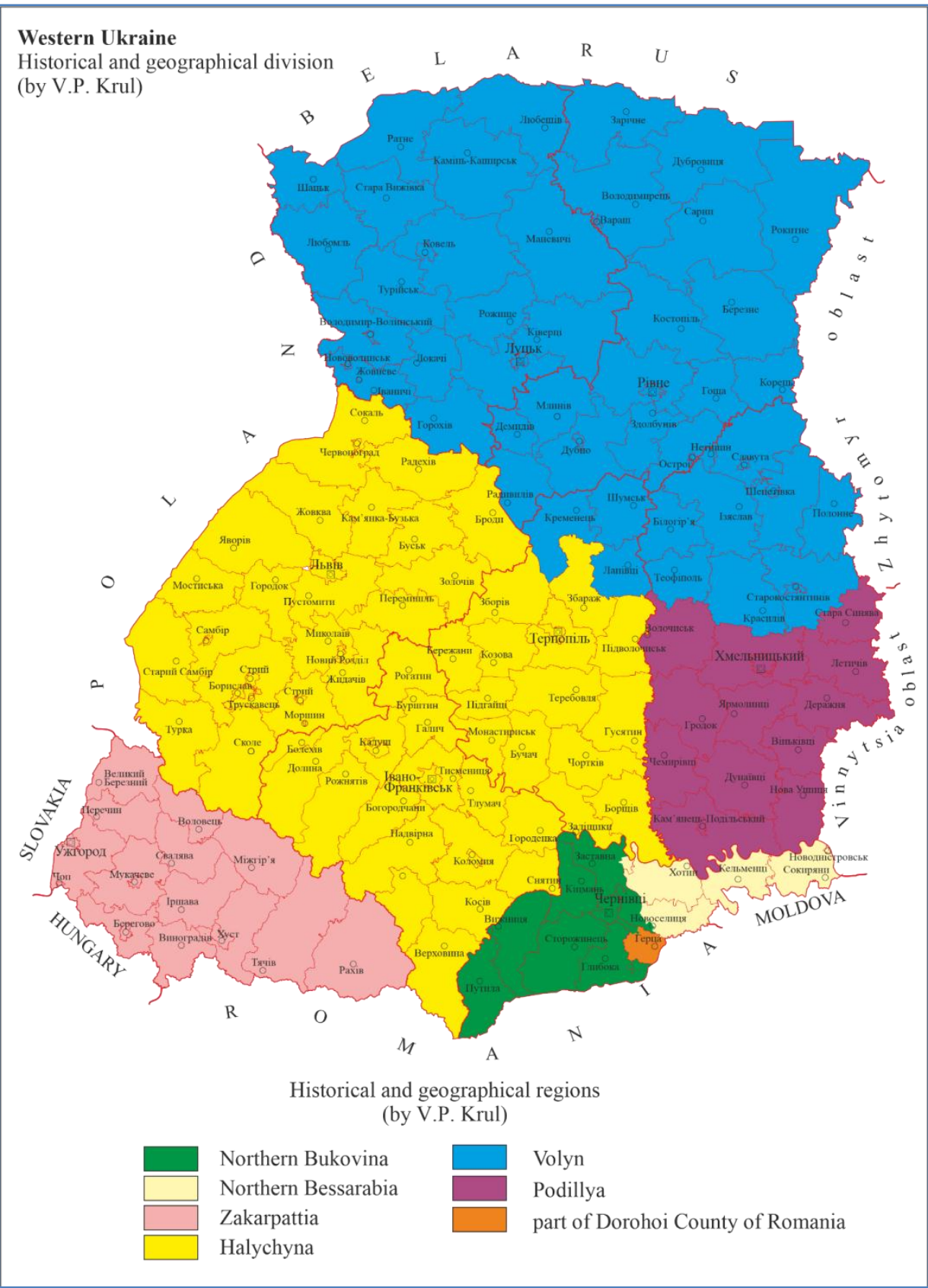

Fig. 1. Historical and geographical regions of Western Ukraine (according to V.P. Krul) [1] 
In terms of general indicators - area, population, number of settlements, national population structure, etc., there are significant differences between Western Ukraine and other regions of Ukraine (Table 1).

As you can see from the table, there are quite significant differences between the area, population and number of settlements in Western Ukraine and other regions of Ukraine. The study region accounts for $21.7 \%$ of the area of Ukraine and $23.7 \%$ of the population.

The ratio of general indicators of the territory of Western Ukraine and other regions [5]

Table 1

\begin{tabular}{|c|c|c|c|c|c|c|}
\hline \multirow{3}{*}{ Territory } & \multicolumn{6}{|c|}{ Indicators* } \\
\hline & \multirow{2}{*}{$\begin{array}{l}\text { Area } \\
\left(\mathrm{km}^{2}\right)\end{array}$} & \multirow{2}{*}{$\begin{array}{l}\text { Population } \\
\text { (people) }\end{array}$} & \multirow{2}{*}{$\begin{array}{l}\text { Number } \\
\text { of regions }\end{array}$} & \multicolumn{3}{|c|}{ Number of settlements } \\
\hline & & & & cities & smt & villages \\
\hline Western Ukraine & 131266 & 10574173 & 8 & 134 & 164 & 8081 \\
\hline Western Ukraine (\%) & 21,7 & 23,7 & 32,0 & 29,1 & 18,5 & 28,5 \\
\hline Other regions of Ukraine & 472393 & 34012941 & 17 & 326 & 721 & 20304 \\
\hline Other regions of Ukraine $(\%)$ & 78,3 & 76,3 & 68,0 & 70,9 & 81,5 & 71,5 \\
\hline All Ukraine & 603659 & 44587114 & 25 & 460 & 885 & 28385 \\
\hline
\end{tabular}
1, 2014

*Taking into account the data for the Autonomous Republic of Crimea, Sevastopol, Donetsk and Luhansk oblasts as of January

According to the national structure of the population, these two parts of Ukraine also differ markedly (Table 2). Western Ukraine is a region with a high proportion of ethnic Ukrainians (92.4\%), while in other oblasts this figure is much lower at only $73.5 \%$. Russians predominate among ethnic minorities, but with a significant difference in proportion $(2.8 \%$ in Western Ukraine and $21.5 \%$ in other oblasts). In the study region, Hungarians (1.4\%) and Romanians (1.3\%) have a significant share in ethnic composition, and in other oblasts the third largest ethnic minority is Crimean Tatars, not exceeding even $1 \%$ and occupying only
$0.7 \%$. in the proportion of national population.

Such general differences between Western Ukraine and other regions of Ukraine are usually a significant factor in the formation of religious space and its components. The regions of Western Ukraine have long been more religiously active than other regions of Ukraine. This can be explained by the fact that the region we studied was the latest to become part of the atheistic Soviet Union, which, of course, had a positive effect on the preservation of both religious buildings and low levels of atheism. This is confirmed by the data shown in table 3 .

Comparison of the ethnic structure of the population of Western Ukraine and other regions (2001) [6]

\begin{tabular}{|c|c|c|c|c|c|c|c|c|c|c|c|c|c|}
\hline & \multicolumn{13}{|c|}{ Ethnic population groups, \%\% } \\
\hline & 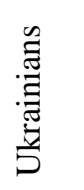 & 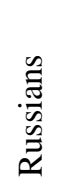 & 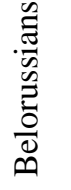 & 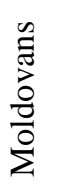 & 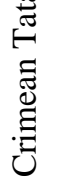 & 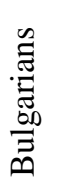 & 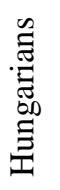 & 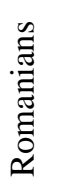 & $\frac{\tilde{\theta}}{0}$ & $\stackrel{0}{3}$ & 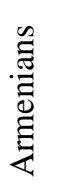 & $\begin{array}{l}\frac{n}{d} \\
\stackrel{d}{0}\end{array}$ & $\frac{\tilde{d}}{\stackrel{5}{0}}$ \\
\hline Western Ukraine & 92,4 & 2,8 & 0,3 & 0,7 & 0,0 & 0,0 & 1,4 & 1,3 & 0,5 & 0,1 & 0,0 & 0,0 & 0,5 \\
\hline $\begin{array}{l}\text { Other regions } \\
\text { of Ukraine }\end{array}$ & 73,5 & 21,5 & 0,7 & 0,5 & 0,7 & 0,5 & 0,0 & 0,0 & 0,2 & 0,3 & 0,3 & 0,2 & 1,5 \\
\hline
\end{tabular}
1,2014

Dynamics of religious communities of Western Ukraine in comparison with other regions [4, 7, 8]

\begin{tabular}{|c|c|c|c|c|}
\hline \multirow{2}{*}{ Territory } & \multicolumn{4}{|c|}{ Years } \\
\hline & 1988 & 1998 & 2008 & 2018* \\
\hline Western Ukraine (number of communities) & 3700 & 10676 & 13241 & 14981 \\
\hline Western Ukraine (\%) & 59,9 & 52,3 & 41,4 & 39,0 \\
\hline Other regions of Ukraine (number of communities) & 2479 & 9730 & 18777 & 23423 \\
\hline Other regions of Ukraine $(\%)$ & 40,1 & 47,7 & 58,6 & 61,0 \\
\hline All Ukraine (\%) & 6179 & 20406 & 32018 & 38404 \\
\hline
\end{tabular}
1,2014 
As can be seen from the table, in the early 90s of the twentieth century in Western Ukraine there were 3700 religious communities, which was $59.9 \%$. However, after the proclamation of Independence and the permission of the free religion, this figure began to decline due to the fact that in other areas new churches are being restored and opened, new denominations, trends and currents are emerging. However, even today in Western Ukraine there are $39 \%$ of all communities registered in Ukraine, which confirms the importance of the studied region and proves that it is quite interesting in the religious aspect of its development, as well as in the development of individual regions by their confessional and national structure.

Indicators of confessional mosaicism and provision of the population with religious communities are also interesting (Table 4).

Provision of the population with religious communities of Western Ukraine in comparison with other regions

\begin{tabular}{|c|c|c|c|c|}
\hline \multirow{2}{*}{ Territory } & \multicolumn{4}{|c|}{ Indicators* } \\
\cline { 2 - 5 } & $\begin{array}{c}\text { Confessional } \\
\text { mosaic index }\end{array}$ & $\begin{array}{c}\text { Number of } \\
\text { communities per } \\
1000 \text { inhabitants }\end{array}$ & $\begin{array}{c}\text { Number of } \\
\text { communities per } \\
100 \mathrm{~km}^{2}\end{array}$ & $\begin{array}{c}\text { Number of } \\
\text { communities per } \\
1 \text { settlement }\end{array}$ \\
\hline Western Ukraine & 0,70007 & 1,4 & 11,4 & 1,8 \\
\hline Other regions of Ukraine & 0,73586 & 0,7 & 5,0 & 1,1 \\
\hline All Ukraine & 0,80202 & 0,9 & 6,4 & 1,3 \\
\hline
\end{tabular}
1, 2014

*Taking into account the data for the Autonomous Republic of Crimea, Sevastopol, Donetsk and Luhansk oblasts as of January

After analyzing this table, we can conclude that the index of confessional mosaic is the highest in Ukraine as a whole (0.80202), and the lowest in Western Ukraine (0.70007). This is due to the fact that the confessional structure of the studied region is not too diverse, i.e. there are denominations that have their own stability, and new directions do not penetrate significantly. In other regions of Ukraine, the share is diverse, because in their territory there are large shares of Protestant communities. When calculating the indicator for Ukraine, the share becomes variegated, as it combines many denominations that are traditional for Western Ukraine (UGCC, ZRC, etc.).

Indicators of the provision of the population with religious communities reflect the geospatial features of community distribution. The indicator of the provision of the population with religious communities (number of communities per 1000 inhabitants) shows that it is twice as high in the western regions of Ukraine as in other regions, and the indicator of localization of religious communities in a certain area (number of communities per $100 \mathrm{~km}^{2}$ ) shows a larger amplitude - in Western Ukraine it is 11.4 compared to other regions - 5.0 communities $/ 100 \mathrm{~km}^{2}$; the indicator reflecting the number of communities per 1 settlement in the study region is 1.8. It is higher than in other regions of Ukraine $(1,1)$, which can be explained by the predominance of rural settlements.

Given these indicators, we can conclude that the religious space of the regions of Western Ukraine is markedly different from other regions. This is confirmed by the fact that the study region at the local level (settlement level) in order to identify the geographical features of the formation of religious space was chosen appropriately.

The confessional space of Western Ukraine is represented by Orthodox, Catholic, Protestant, Jewish, Muslim, Buddhist subspaces and other denominations.

The Orthodox subspace is represented by the activities of the following major denominations in the study region: the Ukrainian Orthodox Church of the
Moscow Patriarchate (UOC-MP), the Orthodox Church of Ukraine (OCU), which was formed at the Unification Council on December 15, 2018, as a result of the merger of the Ukrainian Orthodox Church (UOC) and the Ukrainian Autocephalous Orthodox Church (UAOC) and other Orthodox churches.

The UOC-MP is the dominant direction in terms of the number of communities in five oblasts, namely: Volyn, Rivne, Khmelnytskyi, Chernivtsi and Zakarpattia. There are almost no its communities in the historical and geographical region of Halychyna (Fig. 2). Communities of this denomination operate in almost all village councils in Chernivtsi and Zakarpattia oblasts, in the other three oblasts there are a small number of settlements where UOC-MP communities do not operate, and sometimes (especially in Polissya) no communities are registered due to low population (usually up to 200 people). For example, in southern and eastern Ukraine, there are no religious communities in settlements of up to 500 people, which is associated with low religious activity caused by prolonged atheistic propaganda.

The OCU is the second largest Orthodox denomination in the Western Ukrainian region. It is represented in all areas. However, its communities are absent in part of the former Dorohoi district (Hertsaiv raion of Chernivtsi oblast), have a small number of communities in Zakarpattia (up to 50 communities) and Northern Bessarabia (up to 15 communities). In most districts of Halychyna it is the second largest denomination. It is best represented in Northern Bukovyna (Zastavna, Kitsman and Vyzhnytsia raions), Volyn and Halychyna, as well as Podillya, which is represented by Khmelnytskyi oblast.

Other Orthodox denominations in Western Ukraine are represented by the Russian Orthodox Old Believer Church (Bilokrynytsia Consent) - Chernivtsi oblast (10 communities), Khmelnytskyi oblast (5), the Russian Orthodox Old Believer Church (Consent without priests) - Zakarpattia Oblast (1 community), and others religious 
communities, which for the most part do not belong to any Orthodox group and have a so-called "local character", i.e. are represented in only one, at most three regions (the Orthodox Church of the Mother of God).
They are concentrated in six oblasts: Volyn (2 communities), Zakarpattia (3), Lviv (2), Rivne (1), Khmelnytskyi (2) and Chernivtsi (2) [4].

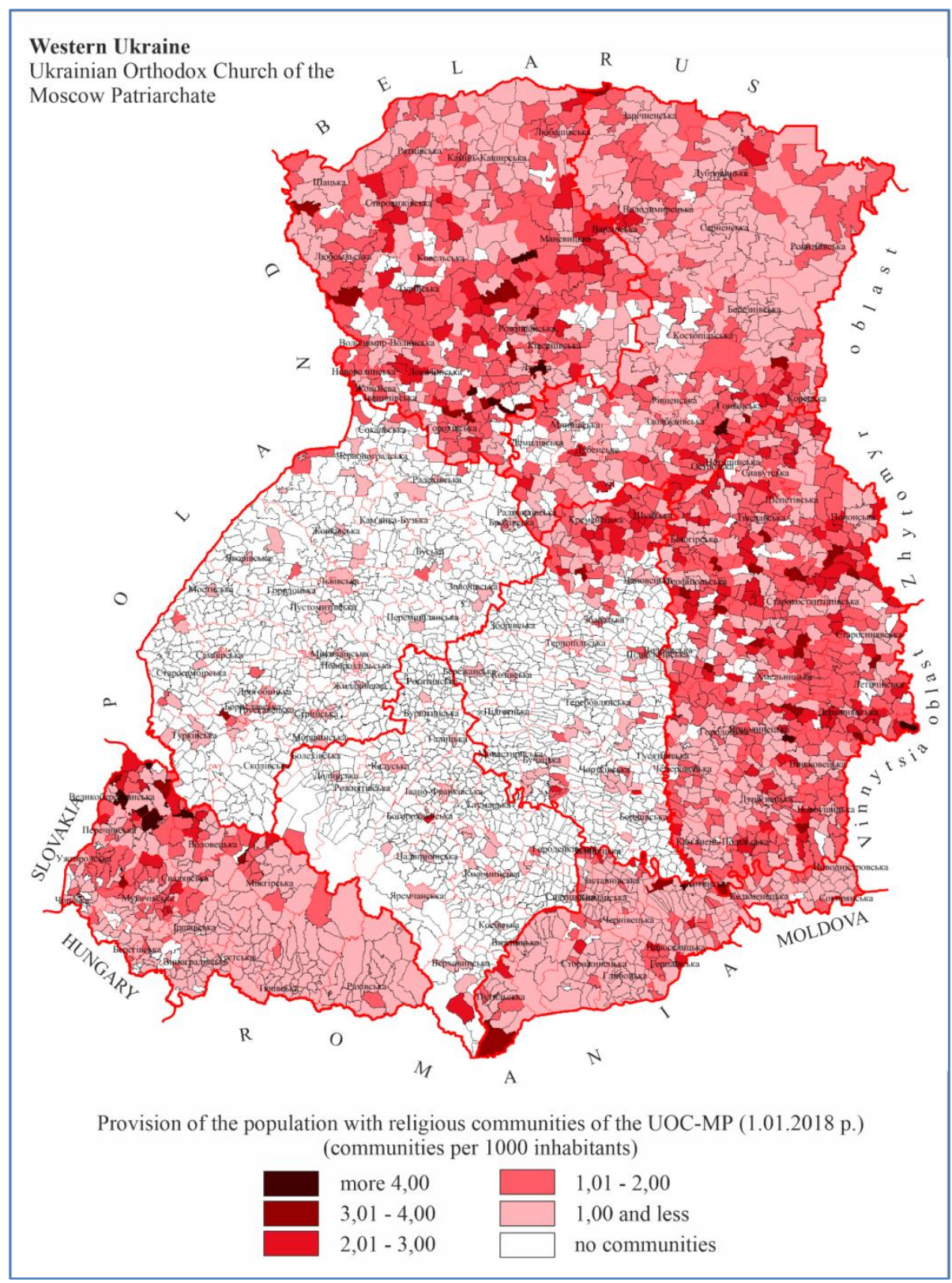

Fig. 2. Provision of the population with UOC-MP communities in Western Ukraine

The Catholic subspace on the territory of Western Ukraine is the most represented among all regions of Ukraine. It provides for four denominations, namely the RCC, the UGCC, the MGKE and the Armenian Catholic Church (Appendix D.2 and E).

The UGCC, together with the MGKE, which is widespread only in the Zakarpattia oblast, is the largest among Catholic denominations in the region and ranks second in the number of communities after the UOC-MP (Fig. 3). It is clear from the map that most of the communities of Eastern Catholic churches fall on the territory of Halychyna and Zakarpattia, which can be explained by the long entry of these areas into the Commonwealth and its successor - Poland, as well as the support of the higher clergy at different times in Florence (1439). and the Brest Union (1596). According to the official website of the UGCC, "In Halychyna, where Polish-Ukrainian antagonism was particularly acute and tense, the Church united with Rome gained the support of the Orthodox hierarchy and the faithful almost a century after Brest (only in 1691 the Peremyshl diocese and as early as 1700 - Lviv). The Synod of Zamostia in 1720 granted the Union Church the status of the only Church of the Eastern Rite in the lands of the Commonwealth" [4]. It should be noted that Greek Catholics could not establish themselves in the territory of Volyn due to the refusal and opposition of the union of the higher clergy. 


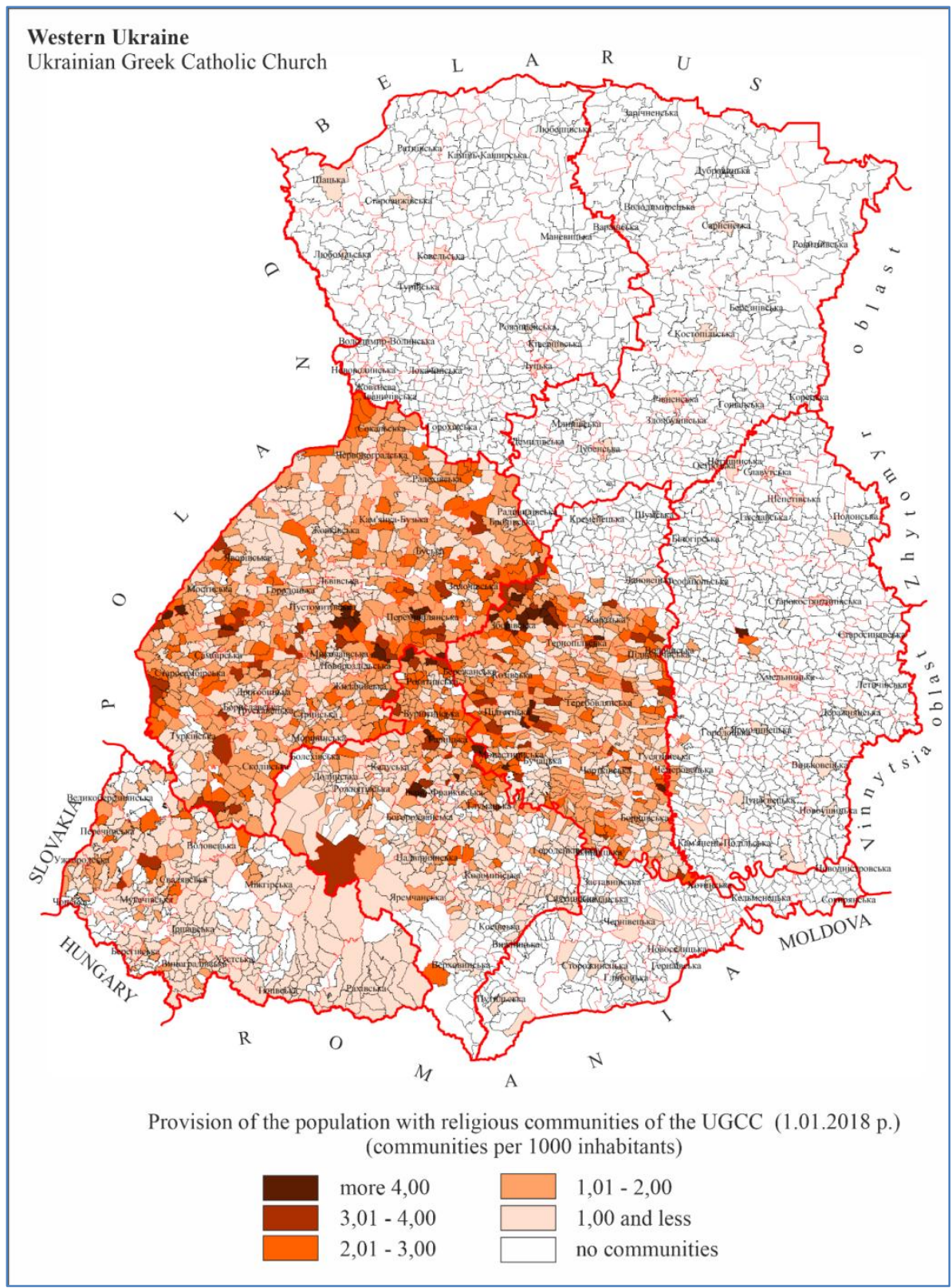

Fig. 3. Provision of the population with the communities of the UGCC and MGKE in Western Ukraine

It is interesting that the UGCC prevails where there are practically no communities of the UOC-MP, and in the Orthodox space a prominent place is occupied by the UOC-KP and the UAOC. This is explained by the fact that the Greek Catholic Church, which operated underground en masse, after being allowed to practice religion freely in 1988, ousted the UOC-MP, which was then an exarchate of the Russian Orthodox Church, through educational activities and supporting Ukrainians in the struggle for independence of Ukraine, etc. It should be noted that the analysis of statistical data on the number of UGCC communities before its ban in 1945 and at the beginning of the XXI century shows that it has managed to regain its position in Western Ukraine and increase the number of communities in other regions of Ukraine. The transfer of the patriarchal center from Lviv to Kyiv became important.

The RCC is a fairly common church in the study region and is represented in all oblasts. Its territorial organization clearly correlates with the spread of ethnic Poles and Hungarians in the region. Most communities operate in Khmelnytskyi (the share of Poles in the ethnic structure of the population is $1.7 \%)$, Lviv $(0.7 \%$ of Poles), Ternopil $(0.3 \%$ of Poles), Chernivtsi $(0.4 \%$ of Poles) and Zakarpattia (12, 1\% of Hungarians) oblasts [7]. In Zakarpattia, the RCC did not gain an absolute advantage even in those areas where Hungarians constitute an absolute majority, because many of them moved from Catholicism to Protestantism, founding one of the Lutheran churches, the Transcarpathian Reformed Church. There is one community of the Armenian Catholic Church in Khmelnytskyi oblast.

The Protestant space of Western Ukraine is represented by all current denominations in Ukraine, trends and currents that shape it. The largest Protestants by number of communities are the ECB and the UPC. 
The ECBs are represented in the region by certain areas: Transcarpathian, North Bessarabian, South Podillya and South Volyn. There are almost no ECB communities in Halychyna, where they are mostly distributed in large cities. Their territorial organization is also explained by the historical features of distribution. Analyzing their official website, we read: "In the western Ukrainian lands that were part of Poland, evangelical Christians became most widespread in Volyn and Polissya (96\%) and are almost not represented in Halychyna" [2].

The UPC in the region is most noticeable in Volyn, Northern Bukovina and Zakarpattia. The least of their communities operate in Halychyna and Podillya, where they are concentrated mainly in large and medium-sized cities. According to the official website of the Ukrainian Church of Evangelical Christians, the main reason for the spread of Pentecostalism in Volyn was the arrival here in 1919 of Ukrainian peasants who were working in the United States [3]. Therefore, the spread of UPC in the study region was influenced by migratory factors.

The geospatial organization of the smaller Protestant denominations, in particular the SDA and the JW, proved to be interesting. They do not have clearly defined areas of their distribution, but in fact evenly distributed throughout the study region, which allows for the most effective missionary, prayer, social and other activities and to cover a larger population. In our opinion, this geography of their communities is somewhat planned, focused on medium and large cities, as well as the transport accessibility of the population to houses of prayer or meeting places.

These denominations are mostly represented in Zakarpattia oblast, and the SDA forms a vague area in Chernivtsi oblast. The SDAs have the fewest communities in Halychyna.

The TRC is distributed only in Zakarpattia oblast and has 117 communities. It is spread along the state border of Ukraine with Romania, Hungary and Slovakia in Uzhhorod, Mukachevo, Berehovo and Vynohradiv raions, where a significant proportion of ethnic Hungarians live $(33.4 \% ; 12.7 \% ; 76.1 \%$ and $26.2 \%$, respectively), as well as in the cities of regional significance - Uzhhorod, Berehove, Khust and Mukachevo $(6.9 \% ; 48.1 \% ; 5.4 \%$ and $8.5 \%$ of Hungarians in the share of urban population) $[4,6]$.

To the group of other Protestants we include a number of denominations, trends and currents that do not have a significant number of religious communities and do not form separate areas of geospatial organization. Usually they include completely new denominations for Ukraine, which appeared here during the years of Independence: the Church of Jesus Christ of Latter-day Saints (Mormons), Lutheran denominations, the Evangelical Reformed Church, the Association of Independent Charismatic Christian Churches of Ukraine (Full Gospel), the Church of the Living God and many others. Representatives of other Protestants became most widespread in Zakarpattia and Polissya of Rivne oblast, which can be explained in the first case by the polyethnic composition of the population, and in the second - the presence of settlements where communities of other Protestants are insignificant.
The non-Christian subspace is represented by Jewish, Buddhist, Islamic, pagan components, as well as new religious movements, which are not included in any of the denominational spaces and subspaces we have identified. The Jewish area is one of the largest in number of communities in Western Ukraine and has 10 communities in Lviv oblast, 4 in Ternopil oblast, 3 in Ivano-Frankivsk oblast, 14 in Chernivtsi oblast, 12 in Zakarpattia oblast, 19 in Khmelnytskyi oblast, 2 in Volyn oblast and 5 in Rivne oblast. It should be noted that Buddhists, Islam, religions of the East, pagans operate mostly in large cities - oblast centers, and have from 1 to 5 communities. Spread among immigrants who permanently reside or come here to study.

Thus, it can be traced that the confessional space of Western Ukraine was formed under the influence of many groups of factors in the process of a long and complex process of formation of the territory of Ukraine. Today it is represented by both traditional denominations and new trends.

Conclusions of the study. During the study we revealed the place of oblasts of Western Ukraine among other regions in terms of religious activity and analyzed the confessional structure of eight oblasts (Volyn, Zakarpattia, Ivano-Frankivsk, Lviv, Ternopil, Rivne, Khmelnytskyi and Chernivtsi) at the level of settlements. These regions include the following historical and geographical regions (by V.P. Krul): Zakarpattia, Halychyna, Northern Bukovina, Northern Bessarabia, part of Dorohoishchyna, part of Podillya and Volyn, which allows to better trace the influence of historical, geographical, ethnic and other factors on the process formation of religious space.

The study region accounts for $21.7 \%$ of the area of Ukraine and $23.7 \%$ of the population, where $39 \%$ of all religious communities registered in Ukraine operate, and the localization rate of religious communities (number of communities per $100 \mathrm{~km}^{2}$ ) in the Western Ukraine is 11.4 compared to other regions - 5.0 communities/100 $\mathrm{km}^{2}$. This confirms the importance of this region in the religious life of the state.

The Orthodox subspace in the region is represented in all directions. The most numerous in terms of the number of communities are the UOC-MP and the OCU (UOC-KP and UAOC). It is interesting that the UOCMP has significant advantages in the Hertsaiv raion of Chernivtsi oblast (part of the former Dorohoi county), as well as in the territory of Northern Bessarabia. In Halychyna, the Orthodox communities are dominated by the OCU, and in Volyn and Podillya - the OCU and the UOC-MP. This confirms that religious space can serve as one of the indicators of the boundaries of historical and geographical lands.

The Catholic subspace is represented by the UGCC, the Mukachevo Greek Catholic Diocese (MGKD), the RCC and the Armenian Catholic Church. The UGCC, together with the MGKE, which is widespread only in Zakarpattia oblast, is the largest among Catholic denominations in the region and ranks second in the number of communities after the UOC-MP. The territorial organization of the UGCC and MGKE communities is interesting, which is shown in Fig. 8, 
which clearly delineate the north-eastern and eastern borders of Halychyna.

The Protestant subspace is represented by many denominations, trends and currents, the most numerous of which are ECB, UPC, SDA, Jehovah's Witnesses. An interesting feature is that the smallest Protestant communities are represented in Halychyna, and the most noticeable of their influence is in Northern Bukovina and Northern Bessarabia, Volyn and Podillya. This is due to the religious affiliation of the population.

The non-Christian subspace is represented by Jewish communities of different currents, Muslims and various pagan and ethno-religious communities. Their number in the region is insignificant and common mainly in urban settlements.

The number of archirs, agnostics and atheists in the regions of Western Ukraine ranges from $1.5 \%$ (Lviv oblast) to $4.7 \%$ (Khmelnytskyi oblast).

Thus, in Western Ukraine there are quite noticeable territorial differences in the confessional space, which is explained by the peculiarities of the formation of the territory of Ukraine, the domination of different states at different times.

\section{Список використаних джерел:}

1. Круль В.П. Краєзнавство: історична географія. Чернівці: Чернівецький держ. ун-т ім. Ю. Федьковича, 1999. $107 \mathrm{c}$.

2. Контент офіційного сайту СХБ. Режим доступу: https://www.baptyst.com (дата звернення: 07.10.2020).

3. Контент офіційного сайту ХВСП. Режим доступу: http://www.chve.org.ua (дата звернення: 07.10.2020).

4. Контент-матеріали Релігійно-інформаційної служби України. Режим доступу: https://risu.org.ua (дата звернення: 07.10.2020).

5. Матеріали Державної служби статистики України. Режим доступу: http://www.ukrstat.gov.ua (дата звернення: 07.10.2020).

6. Матеріали офіційної сторінки перепису населення України - 2001. Режим доступу: http://2001.ukrcensus.gov.ua (дата звернення: 07.10.2020).

7. Статистична інформація Департаменту у справах релігій та національностей Міністерства культури України. Режим доступу: http://mincult.kmu.gov.ua/control/uk (дата звернення: 07.10.2020).

8. Статистичні звіти Міністерства культури України. Режим доступу: http://mincult.kmu.gov.ua/control/uk (дата звернення: 07.10.2020).

\section{References:}

1. Krul, V.P. (1999). Krayeznavstvo: istorychna geografiya [Local studies: historical geography]. Chernivtsi: Chernivetskyi derzh. un-t im. Yu. Fedkovycha [in Ukrainian].

2. Kontent ofitsiynoho saytu YeKhB [Content of the official ECB website]. Retrieved from https://www.baptyst.com [in Ukrainian].

3. Kontent ofitsiynoho saytu KhVIeP [Content of the official UPC website]. Retrieved from http://www.chve.org.ua [in Ukrainian].

4. Kontent-materialy Relihiyno-informatsiynoi sluzhby Ukrainy [Content materials of the Religious Information Service of Ukraine]. Retrieved from https://risu.org.ua [in Ukrainian].

5. Materialy Derzhavnoi sluzhby statystyky Ukrainy [Materials of the State Statistics Service of Ukraine]. Retrieved from http://www.ukrstat.gov.ua [in Ukrainian].

6. Materialy ofitsiynoi storinky perepysu naselennya Ukrainy - 2001 [Materials of the official page of the census of Ukraine - 2001]. Retrieved from http://2001.ukrcensus.gov.ua [in Ukrainian].

7. Statystychna informatsiya Departamentu u spravakh relihiy ta natsionalnostey Ministerstva kultury Ukrainy [Statistical information of the Department for Religions and Nationalities of the Ministry of Culture of Ukraine]. Retrieved from http://mincult.kmu.gov.ua/control/uk [in Ukrainian].

8. Statystychni zvity Ministerstva kultury Ukrainy [Statistical reports of the Ministry of Culture of Ukraine]. Retrieved from http://mincult.kmu.gov.ua/control/uk [in Ukrainian].

Надійшла до редколегї 06.11.2020 p.

\section{Про автора:}

Іван Костащук - доктор географічних наук, доцент кафедри географії України та регіоналістики, Чернівецький національний університет імені Юрія Федьковича, вул. М. Коцюбинського 2, корп. 4, м. Чернівці, 58012, Україна, ivan_kostaschuk@ukr.net, https://orcid.org/0000-0002-9338-4538

\section{Об авторе:}

Иван Костащук - доктор географических наук, доцент кафедры географии Украины и регионалистики, Черновицкий национальный университет имени Юрия Федьковича, ул. М. Коцюбинского, 2, корп. 4, г. Черновцы, 58012, Украина, ivan_kostaschuk@ukr.net, https://orcid.org/0000-0002-9338-4538 